\title{
THE ABSOLUTE STEREOCHEMISTRY AND CYTOTOXICITY OF THE ASCIDIAN-DERIVED METABOLITE, LONGITHORONE J
}

\author{
ROHAN A. DAVIS, ${ }^{\mathrm{a}}$ ANTHONY R. CARROLL, ${ }^{\mathrm{a}}$ DIANNE WATTERS, ${ }^{\mathrm{b}}$ and \\ RONALD J. QUINN ${ }^{\text {a,* }}$ \\ ${ }^{a}$ Natural Product Discovery, Eskitis Institute, Griffith University, Brisbane, QLD 4111, Australia \\ ${ }^{\mathrm{b}}$ Cell Biology, Eskitis Institute, Griffith University, Brisbane, QLD 4111, Australia
}

\footnotetext{
* Corresponding author. Tel.: $61 \quad 7 \quad 3735$ 6006. Fax: $61 \quad 7 \quad 3735$ 6001. E-mail: r.quinn@griffith.edu.au
} 
The absolute stereochemistry of longithorone J (1) from the ascidian Aplidium longithorax has been determined using the advanced Mosher method. Based on biosynthetic reasoning and chiroptical data comparison the absolute stereochemistry for longithorone K (2) was also assigned. Longithorone J was tested for cytotoxicity against the cell lines SHSY5Y, HEK293T and A549. Compound 1 showed minimal cytotoxicity towards the SHSY5Y and HEK293T cell lines.

Keywords: Ascidian; Aplidium longithorax.; Natural product; Longithorone J; Longithorone K; Absolute stereochemistry; Mosher method; Cytotoxicity 


\section{INTRODUCTION}

Longithorones $\mathrm{A}-\mathrm{K}$ are a unique class of macrocylic $\mathrm{C}_{21}$ or $\mathrm{C}_{42}$ prenylated quinone derivatives, which have all been isolated from ascidian sources. Longithorones A -I were isolated from Aplidium longithorax collected in Palau as part of a search for new antitumour agents from marine sources [1,2], while longithorones $\mathbf{J}$ (1) and K (2) were purified during chemical investigations of an Australian A. longithorax [3] (Figure 1). To date the only biological activity reported for these marine metabolites pertains to longithorone A (3), which was shown to display cytotoxicity against P388 murine leukemia cells with an $\mathrm{IC}_{50}$ of $\sim 10 \mu \mathrm{g} / \mathrm{mL}[1]$. In the first reported isolation of longithorones $\mathrm{J}$ and $\mathrm{K}$ it was noted that both metabolites were unstable in $\mathrm{CDCl}_{3}[3]$. Although the gross structures and relative stereochemistry of both $\mathbf{1}$ and $\mathbf{2}$ were elucidated, their instability prevented further stereochemical analyses or biological testing. Recently we have re-isolated longithorone $\mathrm{J}(\mathbf{1}, 0.7 \mathrm{mg})$ from a fraction resulting from the initial chemical investigations of A. longithorax. This paper reports the absolute stereochemistry of longithorone $\mathrm{J}$ using the advanced Mosher method and the cytotoxicity of $\mathbf{1}$ against the cell lines SHSY5Y, HEK293T and A549. The absolute stereochemistry of longithorone K (2) is also reported. 


\section{RESULTS AND DISCUSSION}

A fraction obtained during the initial chemical investigations of $A$. longithorax was subjected to the previously published chromatographic protocol used for the isolation of 1 and 2 [3]. This yielded a pure compound (1, $0.7 \mathrm{mg}$ ) which was spectroscopically identical to the previously published data for longithorone $\mathrm{J}$ [3].

Prior to synthesizing the MTPA esters of compound 1, molecular modeling studies using Macromodel ${ }^{\circledR}$ were performed in order to determine whether the secondary alcohol at C-17 was located in a sterically crowded environment. It has been reported that sterically hindered alcohols can produce erroneous assignments of absolute stereochemistry when using the advanced Mosher method [4,5]. MonteCarlo conformational searching found 181 unique conformations for $\mathbf{1}$ with the global minimum energy conformation $(\mathrm{E}=71.01 \mathrm{kcal} / \mathrm{mol})$ occurring 40 times. Analysis of all 181 conformers revealed that $17-\mathrm{OH}$ was unhindered. Low energy conformer $2(\mathrm{E}=71.66 \mathrm{kcal} / \mathrm{mol})$ (Figure 2) appeared to best fit the previously reported experimental NMR data [3]. The ${ }^{1} \mathrm{H}-{ }^{1} \mathrm{H}$ coupling constants calculated from this conformer between $\mathrm{H}-16$ and $\mathrm{H}-21 \alpha / \mathrm{H}-21 \beta$ were almost identical to the observed coupling constants in the initial structure elucidation studies $\left[J_{\mathrm{H} 16, \mathrm{H} 21 \alpha}\right.$ $4.8 \mathrm{~Hz}$ (obsd) [3], $4.6 \mathrm{~Hz}$ (calcd); $J_{\mathrm{H} 16, \mathrm{H} 21 \beta} 2.4 \mathrm{~Hz}$ (obsd) [3], $2.0 \mathrm{~Hz}$ (calcd)]. Further analysis of conformer 2 also allowed the distance between H-17 and H- 
$21 \alpha$ to be calculated as $2.60 \AA$. This distance was in agreement with the observed strong ROESY correlation between these $\mathrm{H}-17$ and $\mathrm{H}-21 \alpha$ in 1. [3].

Since 17-OH of $\mathbf{1}$ had been determined to be sterically unhindered the advanced Mosher method [6] was employed. Compound 1 was esterified with the appropriate MTPA-Cl in anhydrous pyridine at room temperature. The (S)-MTPA ester (4) and (R)-MTPA (5) were purified by DIOL SPE followed by DIOL semipreparative HPLC. Compounds $\mathbf{4}$ and $\mathbf{5}$ were characterised using ${ }^{1} \mathrm{H}$ and gCOSY NMR analysis. All proton signals for both compounds could be assigned, and diagnostic ${ }^{1} \mathrm{H}$ NMR chemical shift differences $\left(\delta \Delta=\delta_{\mathrm{S}}-\delta_{\mathrm{R}}\right)$ were calculated. Analysis of the $\delta \Delta$ values (Figure 3) revealed that the absolute stereochemistry of C-17 was $R$. Since the relative stereochemistry of $\mathbf{1}$ had been previously determined the absolute stereochemistry of C-16 was $R$.

Longithorones J (1) and $\mathrm{K}(2)$ differ structurally only on account of their C-17 oxidation state. It is postulated that in nature the selective reduction of 2 would produce $\mathbf{1}$ or the oxidation of $\mathbf{1}$ would afford 2. Based on this biosynthetic reasoning and by comparison of the chiroptical data for $\mathbf{1}$ and $2\left[\right.$ For 1: $[\alpha]_{\mathrm{D}}+170$ (c 0.085, $\left.\mathrm{CH}_{2} \mathrm{Cl}_{2}\right), \mathrm{CD}\left(\mathrm{CH}_{3} \mathrm{OH}\right) 209(\Delta \varepsilon-12.6), 245(\Delta \varepsilon+19.5), 339 \mathrm{~nm}(\Delta \varepsilon-1.8)$; For 2: $[\alpha]_{\mathrm{D}}+61\left(\right.$ c $\left.0.046, \mathrm{CH}_{2} \mathrm{Cl}_{2}\right), \mathrm{CD}\left(\mathrm{CH}_{3} \mathrm{OH}\right) 209(\Delta \varepsilon+1.9), 251(\Delta \varepsilon+1.7)$, 
$376 \mathrm{~nm}(\Delta \varepsilon-0.4)][3]$ we predict $R$ absolute stereochemistry at C-16 for longithorone $\mathrm{K}$.

Longithorone J (1) was tested for cytotoxicity against the cell lines SHSY5Y (human neuroblastoma), HEK293T (SV40 T antigen transformed human embryonal kidney cells), and A549 (human non-small cell lung carcinoma) using the colourimetric sulphorhodamine B assay [7]. Compound $\mathbf{1}$ showed no cytotoxicity in the A549 assay when tested at 2 and $20 \mu \mathrm{g} / \mathrm{mL}$, however 1 displayed minimal activity at $20 \mu \mathrm{g} / \mathrm{mL}$ in the SHSY5Y and HEK293T assays with cell death of $28 \%$ and $16 \%$, respectively. Due to the low cytotoxic activity of 1 and the scarcity of this natural product no further biological evaluations were undertaken.

\section{EXPERIMENTAL}

\section{General}

NMR spectra were recorded at $30^{\circ} \mathrm{C}$ on a Varian $600 \mathrm{MHz}$ Unity INOVA at 599.926 MHz for ${ }^{1} \mathrm{H}$. The ${ }^{1} \mathrm{H}$ chemical shifts were referenced to the solvent peak for $\mathrm{CDCl}_{3}$ at $\delta$ 7.26. Waters 600 pump equipped with a Waters 996 PDA detector and Waters 717 autosampler were used for HPLC. An Alltech DIOL cartridge 
(200 mg, 30-40 $\mu \mathrm{m}, 60 \AA$ A) was used for SPE work. A YMC DIOL column $5 \mu \mathrm{m}$

$120 \AA$ (10-mm D × 150-mm L) was used for HPLC semi-preparative work. All solvents were Merck Omnisolv grade and the $\mathrm{H}_{2} \mathrm{O}$ was Millipore Milli-Q PF filtered. Anhydrous pyridine (Sigma-Aldrich) and (S)- and (R)-MTPA-Cl (Fluka) were used in the preparation of the Mosher esters, paying particular attention that the $(S)$-MTPA-Cl gives the $(R)$-MTPA ester and vice versa.

\section{Animal Material}

Longithorone J (1) was re-isolated from A. longithorax [3] that was collected by scuba diving (-24 m) off Gannet Cay, at the Swains Reefs, Queensland, Australia. Voucher specimen QMG305411 has been deposited at the Queensland Museum, South Brisbane, Queensland, Australia.

\section{Extraction and Isolation}

The re-isolation of longithorone $\mathrm{J}(\mathbf{1}, 0.7 \mathrm{mg})$ was performed using the identical chromatographic protocol to that used for the initial isolation of 1 and 2 [3].

Preparation of MTPA Esters for Longithorone J (1) 
(S)- or $(R)$-MTPA-Cl $(29 \mu \mathrm{L}, 160 \mu \mathrm{mol})$ was added to the starting alcohol $(\mathbf{1}, 0.25$ $\mathrm{mg}, 0.8 \mu \mathrm{mol})$ in anhydrous pyridine $(100 \mu \mathrm{L})$, and the resulting mixture was allowed to stand at room temperature for $4 \mathrm{~h} . \mathrm{CH}_{2} \mathrm{Cl}_{2}(2 \mathrm{~mL})$ was added and the resulting solution was chromatographed over a DIOL packed SPE cartridge (200 mg) using $100 \% \mathrm{CH}_{2} \mathrm{Cl}_{2}(2 \mathrm{~mL})$ as the eluent. The resulting solvent was concentrated under $\mathrm{N}_{2}$ and chromatographed on a DIOL HPLC column using isocratic conditions of $15 \%$ EtOAc/85\% hexanes for $5 \mathrm{~min}$ at $4 \mathrm{~mL} / \mathrm{min}$. The two HPLC separations yielded the pure (S)-MTPA ester of longithorone J (4, $0.2 \mathrm{mg}$, $46 \%$ yield) and the (R)-MTPA ester of longithorone $\mathrm{J}$ (5, $0.2 \mathrm{mg}, 46 \%$ yield).

(S)-MTPA ester of longithorone J (4). Stable yellow gum; ${ }^{1} \mathrm{H}-\mathrm{NMR}(600 \mathrm{MHz}$, $\left.\mathrm{CDCl}_{3}\right): \delta 1.55(3 \mathrm{H}, \mathrm{s}, \mathrm{H}-14), 1.57(3 \mathrm{H}, \mathrm{s}, \mathrm{H}-15), 1.68(1 \mathrm{H}, \mathrm{m}, \mathrm{H}-8 \mathrm{~b}), 1.68(3 \mathrm{H}, \mathrm{s}$, H-13), 1.72 (1H, m, H-9b), 1.83 (1H, m, H-8a), 1.83 (1H, m, H-12b), 1.83 (1H, m, H-9a), 1.91 (1H, ddd, $J=12.6,12.6,4.0$ Hz, H-4b), 2.04 (1H, m, H-5a), 2.15 (1H, m, H-5b), 2.15 (1H, m, H-4a), 2.35 (1H, dd, $J=17.4,4.2 \mathrm{~Hz}, \mathrm{H}-21 \alpha), 2.39(1 \mathrm{H}$, dd, $J=14.4,9.6 \mathrm{~Hz}, \mathrm{H}-1 \mathrm{a}), 2.45$ (1H, dd, $J=13.2,13.2 \mathrm{~Hz}, \mathrm{H}-12 \mathrm{a}), 2.54$ (1H, dd, $J=17.4,4.5 \mathrm{~Hz}, \mathrm{H}-21 \beta), 2.71(1 \mathrm{H}, \mathrm{m}, \mathrm{H}-16), 3.35$ (1H, dd, $J=14.4,9.6 \mathrm{~Hz}, \mathrm{H}-$ 1b), 3.57 (3H, s, MTPA-OCH 3$), 4.89(1 \mathrm{H}, \mathrm{dd}, J=7.2,6.6 \mathrm{~Hz}, \mathrm{H}-6), 4.91(1 \mathrm{H}, \mathrm{m}$, H-2), $5.37(1 \mathrm{H}, \mathrm{dd}, J=7.2,6.6 \mathrm{~Hz}, \mathrm{H}-10), 6.14(1 \mathrm{H}$, br d, $J=5.4 \mathrm{~Hz}, \mathrm{H}-17), 6.34$ (1H, s, H-18), 7.44 (3H, m, MTPA-ArH), 7.57 (2H, m, MTPA-ArH). 
(R)-MTPA ester of longithorone J (5). Stable yellow gum; ${ }^{1} \mathrm{H}-\mathrm{NMR}(600 \mathrm{MHz}$, $\left.\mathrm{CDCl}_{3}\right): \delta 1.56(3 \mathrm{H}, \mathrm{s}, \mathrm{H}-14), 1.48(3 \mathrm{H}, \mathrm{s}, \mathrm{H}-15), 1.68(1 \mathrm{H}, \mathrm{m}, \mathrm{H}-8 \mathrm{~b}), 1.70(3 \mathrm{H}, \mathrm{s}$, H-13), 1.72 (1H, m, H-9b), 1.83 (1H, m, H-8a), 1.60 (1H, m, H-12b), 1.83 (1H, m, H-9a), 1.91 (1H, ddd, $J=12.6,12.6,4.0 \mathrm{~Hz}, \mathrm{H}-4 \mathrm{~b}), 2.04$ (1H, m, H-5a), $2.15(1 \mathrm{H}$, m, H-5b), $2.15(1 \mathrm{H}, \mathrm{m}, \mathrm{H}-4 \mathrm{a}), 2.33(1 \mathrm{H}, \mathrm{dd}, J=17.4,4.9 \mathrm{~Hz}, \mathrm{H}-21 \alpha), 2.41(1 \mathrm{H}$, dd, $J=13.8,4.5 \mathrm{~Hz}, \mathrm{H}-1 \mathrm{a}), 2.38$ (1H, dd, $J=13.2,13.2 \mathrm{~Hz}, \mathrm{H}-12 \mathrm{a}), 2.52(1 \mathrm{H}, \mathrm{dd}$, $J=17.4,1.8 \mathrm{~Hz}, \mathrm{H}-21 \beta), 2.69$ (1H, m, H-16), 3.37 (1H, dd, $J=13.8,10.2 \mathrm{~Hz}, \mathrm{H}-$ 1b), $3.63\left(3 \mathrm{H}, \mathrm{s}, \mathrm{MTPA}-\mathrm{OCH}_{3}\right), 4.89$ (1H, dd, $\left.J=7.2,7.2 \mathrm{~Hz}, \mathrm{H}-6\right), 4.92(1 \mathrm{H}, \mathrm{m}$, H-2), $5.33(1 \mathrm{H}, \mathrm{dd}, J=7.8,7.2 \mathrm{~Hz}, \mathrm{H}-10), 6.13(1 \mathrm{H}$, br d, $J=5.4 \mathrm{~Hz}, \mathrm{H}-17), 6.44$ (1H, s, H-18), 7.44 (3H, m, MTPA-ArH), 7.58 (2H, m, MTPA-ArH).

\section{Molecular Modeling Studies}

Molecular modeling studies were performed using Macromodel ${ }^{\circledR}$ version 6.0 on a Silicon graphics workstation. Monte-Carlo conformational searching was employed using a MM2 force-field and TNCG algorithim. 10000 structures were generated with 181 unique conformations found; all 181 conformations minimised with good convergence.

\section{Cells and Culture Conditions}


The SHSY5Y, HEK293T and A549 cell lines were obtained from the American Type Culture Collection. All cells were maintained in Dulbeccos modified eagle media (DMEM) supplemented with 10\% fetal bovine serum (FBS), penicillin 50 units $/ \mathrm{mL})$ and streptomycin $(50 \mu \mathrm{g} / \mathrm{mL})$. Cultures were incubated at $37^{\circ} \mathrm{C}$ in a humidified $5 \% \mathrm{CO}_{2}$ atmosphere in $\mathrm{T}-25 \mathrm{~cm}^{2}$ tissue culture flasks.

\section{Cell Proliferation Assay}

SHSY5Y, HEK293T and A549 cells were seeded in 96-well culture plates at 4000 cells/well. After $24 \mathrm{~h}$, longithorone J (1) was added to the cells and following $72 \mathrm{~h}$ of drug treatment cell viability was determined by measuring the amount of sulforhodamine B bound to viable-cell protein [7]. Assay results were read using a Molecular Devices Spectra Max 250 plate reader at $520 \mathrm{~nm}$. Longithorone J was tested in triplicate at 2 and $20 \mu \mathrm{g} / \mathrm{mL}$ and was solubilized in $100 \%$ DMSO with a final DMSO concentration of $0.5 \%$ in each well. All three cell lines responded typically when treated with the laboratory standards, lissoclinotoxins E and F [8]. For example, the $\mathrm{IC}_{50}$ of lissoclinotoxin $\mathrm{F}$ towards the HEK293T cells was $\sim 2$ $\mu \mathrm{g} / \mathrm{mL}$.

\section{ACKNOWLEDGMENTS}


R.A.D. acknowledges support provided by a New Researcher Grant from Griffith University.

\section{REFERENCES AND NOTES}

[1] X. Fu, M. B. Hossain, D. van der Helm, F. J. Schmitz (1994) J. Am. Chem. Soc., 116, 12125-12126.

[2] X. Fu, M. B. Hossain, F. J. Schmitz, D. van der Helm (1997) J. Org. Chem., 62, 3810-3819.

[3] R. A. Davis, A. R. Carroll, R. J. Quinn (1999) J. Nat. Prod., 62, 158-160.

[4] I. Ohtani, T. Kusumi, Y. Kashman, H. Kakisawa (1991) J. Org. Chem., 56, 1296-1298.

[5] T. Kusumi, Y. Fujita, I. Ohtani, H. Kakisawa (1991) Tetrahedron Lett., 32, 2923-2926.

[6] I. Ohtani, T. Kusumi, M. O. Ishitsuka, H. Kakisawa (1989) Tetrahedron Lett., 30, 3147-3150.

[7] P. Skehan, R. Storeng, D. Scudiero, A. Monks, J. McMahon, D. Vistica, J. T. Warren, H. Bokesch, S. Kenney, M. R. Boyd (1990) J. Natl. Cancer Inst., 82, 1107-1112.

[8] R. A. Davis, I. T. Sandoval, G. P. Concepcion, R. Moreira da Rocha, C. M. Ireland (2003) Tetrahedron, 59, 2855-2859.

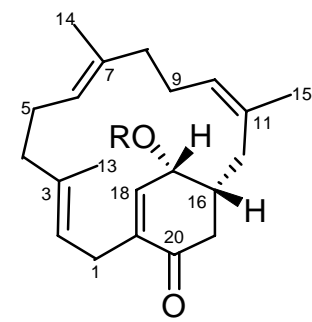

(1) $\mathrm{R}=\mathrm{H}$

(4) $\mathrm{R}=(\mathrm{S})$-MTPA

(5) $\mathrm{R}=(R)$-MTPA

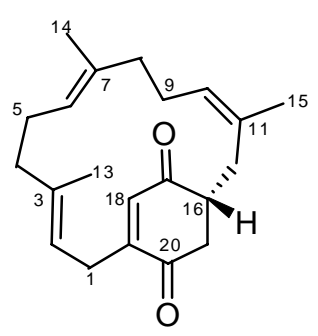

(2)

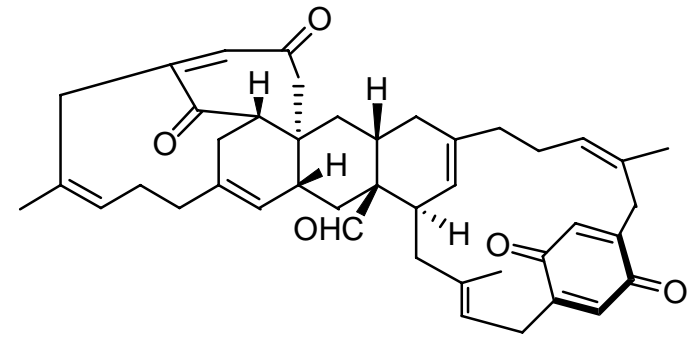

(3)

Figure 1. Chemical structures for compounds 1-5. 


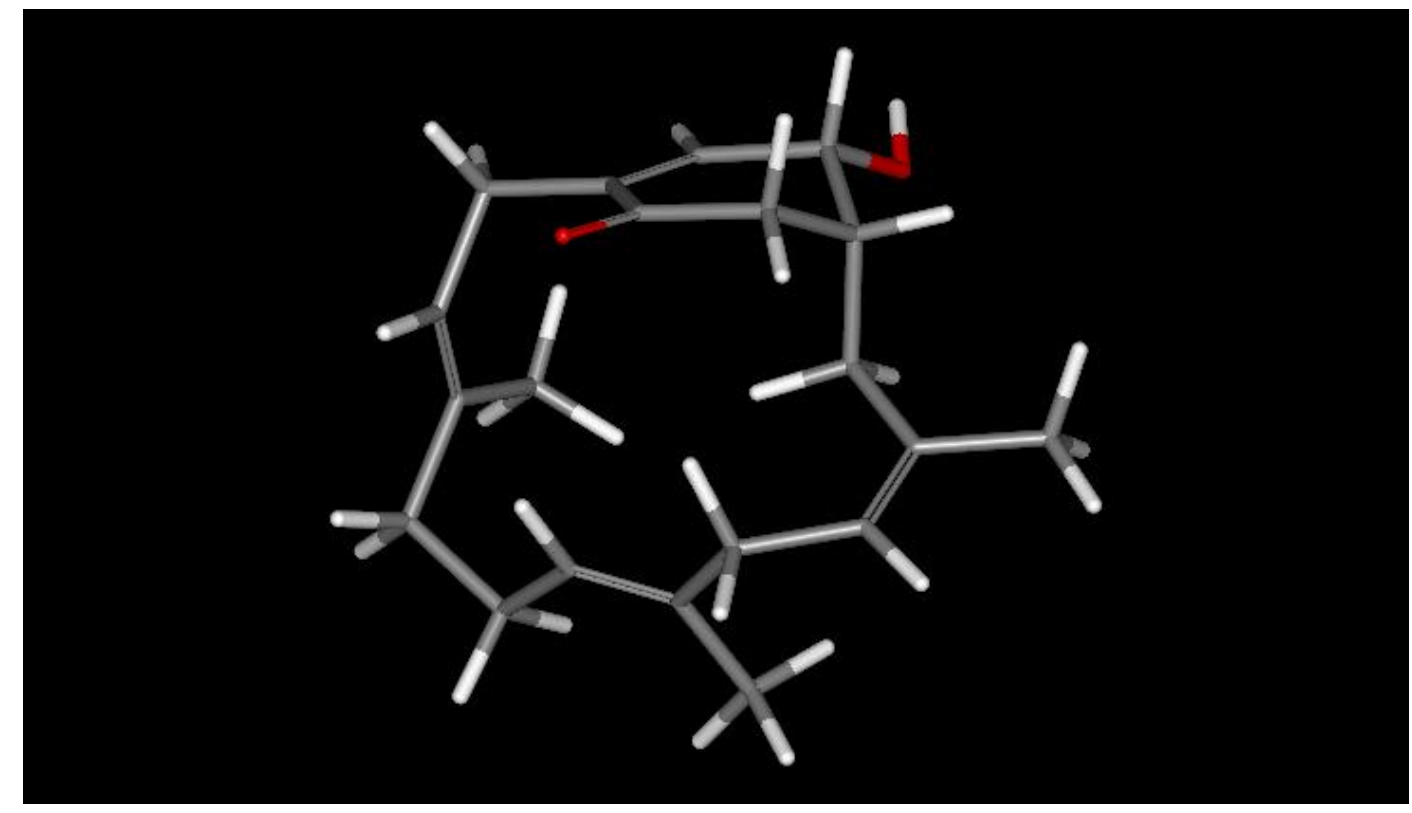

Figure 2. Low energy conformer of longithorone J (1) showing unhindered 17-OH substituent.

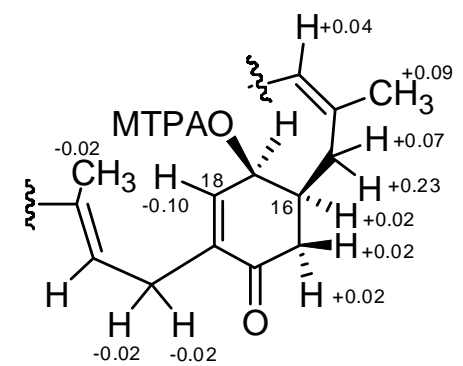

Figure 3. Diagnostic ${ }^{1} \mathrm{H}$ NMR $\delta \Delta$ values (ppm) from Mosher method analysis of 4 and 5. 